Nederlandse Taalkunde

www.nederlandsetaalkunde.nl

Uitgave: Amsterdam University Press

\title{
De detectie van saillante taalkenmerken
}

Een pleidooi voor een multimethodologische benadering

Pieternelle Vandekerckhove \& Anne-Sophie Ghyselen ${ }^{1}$

NT 22 (2): 249-279

DOI: 10.5117/NEDTAA2017.2.VAND

\begin{abstract}
Detecting salient features: in defence of a multidimensional approach

This paper addresses the question how salience, i.e. the perceptual and cognitive prominence of language features (Kerswill \& Williams 2002: 63), can be studied and explained. Within language change studies, the concept of salience is often called upon to explain why certain language features are more prone to change than others, but empirical data to substantiate claims of salience are often lacking or non-convincing. In this paper, an overview is offered of ways in which salience can be studied empirically, building on the insights of recent perceptual dialectological research. It will be argued that a combination of techniques should be strived at, as this allows to combine the strengths of each approach. Subsequently, by offering an overview of existing hypotheses, the question will be addressed how salience can be explained. The formulated insights will be illustrated and tested by means of a multimethodological salience experiment conducted in Flanders. This case study clearly shows (1) the advantage of an approach combining dialect imitation data and several types of interview data and (2) that salience is influenced by a variety of factors, such as the linguistic background of the listener and the context in which the feature occurs.
\end{abstract}

Keywords: salience, circularity, dialect imitation, perception, perceptual dialectology

1 Wij danken twee anonieme reviewers en de redactie van Nederlandse Taalkunde voor hun nuttige commentaren bij een eerdere versie van dit artikel. 


\section{$1 \quad$ Inleiding}

De voorbije decennia treedt perceptueel dialectologisch onderzoek steeds prominenter op de voorgrond in de variatielinguïstiek. Steeds meer onderzoekers besteden aandacht aan de manier waarop taalgebruikers taalvariëteiten en taalvarianten herkennen en categoriseren. De interesse in de percepties van talige leken is op zich niet nieuw - al vanaf het midden van de negentiende eeuw onderzochten pioniers zoals Willem Grootaers, Takesi Sibata en Antonius Weijnen 'subjectieve' dialectgrenzen - maar met de publicatie van het Handbook of Perceptual Dialectology (Long \& Preston 2002, Preston 1999a) en recenter ook de volumes Perceptual Dialectology. Neue Wege der Dialektologie (Anders, Hundt \& Lasch 2010) en Cityscapes and Perceptual Dialectology (Cramer \& Montgomery 2016) profileert het onderzoek naar de perceptie van taalvariatie zich steeds duidelijker als zelfstandige onderzoeksdiscipline. De sturende kracht bij dat onderzoek is de visie dat inzicht in de taalpercepties van de doorsnee taalgebruiker noodzakelijk is om enerzijds taalattitudes, i.e. de evaluaties van percepties $^{2}$, en anderzijds variatiepatronen in de taalproductie beter te kunnen doorgronden (cf. Preston 1999b: xxiv). In die laatste context gaat bijvoorbeeld heel wat aandacht uit naar de vraag hoe taalgebruikers individuele taalkenmerken percipiëren en meer specifiek welke taalvarianten saillant, i.e. cognitief en perceptueel prominent zijn (cf. Hundt, Anders \& Lasch 2010: xi-xii). Welke dialectkenmerken vallen een spreker of hoorder op in zijn eigen taalgebruik of het taalgebruik van anderen en waarom? Die vraag is theoretisch relevant, aangezien saillante kenmerken zich anders zouden gedragen in taalveranderings- en taalcontactsituaties dan niet-saillante. Saillantie wordt in de linguïstiek al lang als verklarend concept gehanteerd: al in 1928 ging Schirmunski ervan uit dat 'opvallende' kenmerken gemakkelijker het voorwerp worden van dialectnivellering dan niet-saillante kenmerken (cf. ook Taeldeman 1993 in het Nederlandse taalgebied), en in 1986 introduceerde Trudgill de term saillantie om te verklaren waarom sommige taalkenmerken sneller onderhevig zijn aan taalaccommodatie dan andere kenmerken (maar zie Hinskens 1992, Ghyselen 2011 en Auer

2 In deze bijdrage maken we een duidelijk onderscheid tussen 'attitudes' en 'percepties', hoewel die twee termen heel vaak samen voorkomen en het verschil tussen beide niet altijd even duidelijk is. Percepties verwijzen naar de manier waarop een taalgebruiker waarneemt, i.e. zintuigelijke informatie ontvangt, verwerkt en categoriseert (cfr. Preston 1989:2). Attitudes daarentegen verwijzen naar de manier waarop een taalgebruiker zijn percepties of waarnemingen evalueert, i.e. bewust of onbewust waarde-oordelen toekent aan een bepaald taalgebruik of een specifieke taalgebruiker. 
2014 voor een kritische beschouwing). Pas met de ontwikkeling van de perceptuele dialectologie is saillantie echter ook het object van empirisch perceptie-onderzoek geworden. Een fundamentele vraag daarbij is hoe de in essentie cognitieve notie empirisch bestudeerd kan worden, aangezien de vrij intuïtieve en soms ook circulaire operationalisering van het concept in het werk van onder andere Trudgill (1986) al vaak bekritiseerd werd (cf. Hinskens 1992: 11-12, Kerswill \& Williams 2002, Auer 2014). Doordat Trudgill (1986) saillantie als verklaring voor taalaccommodatie en taalverandering ziet, maar taalverandering tegelijkertijd als criterium gebruikt om een kenmerk als saillant te bestempelen, verliest het concept saillantie zijn verklarende kracht. Auer, Barden \& Großkopf (1998: 165) pleiten er daarom voor om saillantie te bestuderen op basis van perceptie- en attitudedata, en niet op basis van taalveranderingsdata.

In deze bijdrage gaan we uitgebreider in op de suggestie van Auer, Barden \& Großkopf (1998: 165) en bespreken we hoe saillantie empirisch (niet-circulair) bestudeerd kan worden. In §2 komen verschillende methodologische benaderingen aan bod, waarbij we zullen pleiten voor een combinatie van verschillende technieken. In $\$ 3$ wordt vervolgens stilgestaan bij de factoren die de saillantie van kenmerken kunnen verklaren. In $\$ 4$ illustreren we ten slotte de geformuleerde ideeën aan de hand van een multimethodologisch saillantie-onderzoek dat uitgevoerd werd in Brabant en West-Vlaanderen en dat - voor het eerst in het neerlandistische perceptuele onderzoek - ook dialectimitatiedata incorporeert.

\section{Perceptueel-dialectologische technieken bij saillantie- onderzoek}

Wanneer we saillantie willen bestuderen, moeten we volgens Auer (2014: 89) trachten (1) de oorzaken van saillantie, (2) de criteria voor saillantie of haar verschijningsvormen, en (3) haar effecten op de taalproductie te onderscheiden. Een vermenging van (2) en (3) kan immers tot circulariteit leiden (cf. supra) en om theoretische redenen is het interessanter (1) en (3), de oorzaken en effecten, gescheiden te houden. In deze sectie focussen we op component (2), de verschijningsvormen van saillantie, en bespreken we verschillende types perceptuele data die als uitgangspunt kunnen dienen om de (non-)saillantie van specifieke taalkenmerken te bepalen. 


\subsection{Expliciete bevraging}

Een eerste manier om saillantie op te sporen, is via expliciete bevraging van de taalgebruiker, al dan niet met taalmateriaal als stimulus. Lenz (2010) bijvoorbeeld peilde in sociolinguïstische interviews naar percepties van sprekers over het eigen taalgedrag; wanneer sprekers uitspraken deden over specifieke taalkenmerken (zie bijvoorbeeld Fragment 1), dan werden die metacommunicatieve uitspraken als saillantie-indices beschouwd.

(1) Gut, wenn isch mit Kunden spresch, bemüh isch misch auch, das un was zu sagen. Awer normalerweise, so wie wir jetzt hier reden. [...] Nur wenn isch en guten Eindruck machen muss, un dat is bei mir eigentlisch nur der Fall, ja, in der Firma, jobmäßich, aber sonst, nöö.

'Goed, wanneer ik met klanten spreek, doe ik ook mijn best om $\underline{\text { das }}$ en was te zeggen. Maar normaal gezien, spreek ik zoals wij nu spreken. [...] Alleen wanneer ik een goede indruk moet maken, en dat is bij mij eigenlijk enkel het geval, ja, op het werk, beroepsmatig, maar anders, nee.'

In het Nederlandse taalgebied vinden we een vergelijkbare benadering in het perceptie-onderzoek van Lybaert (2014). Zij legde aan 80 Vlamingen 7 tussentalige of standaardtalige audiofragmenten voor, waarna de informanten mondeling het gehoorde taalgebruik moesten beschrijven en evalueren. De informanten werd expliciet gevraagd hun antwoorden te staven door naar specifieke taalkenmerken te verwijzen, waardoor veel informatie over saillantie verzameld kon worden.

Expliciete bevraging zoals die in Lybaert (2014) en Lenz (2010) heeft duidelijke voor- en nadelen. Het grootste voordeel is dat saillantiedata vrij snel en efficiënt verzameld kunnen worden. Problematisch is dan weer dat de informanten vaak over onvoldoende terminologische bagage beschikken om de gepercipieerde kenmerken te omschrijven, waardoor cruciale informatie over saillantie achterwege blijft. Om dat probleem op te vangen, ontwierp Kleene (te verschijnen) een zogenoemde LingRekTest ('linguistischer Reaktionstest'), waarbij informanten tijdens een computertest stimulifragmenten te horen krijgen en bij het horen van een nietstandaardtalig kenmerk een toets moeten indrukken. Op die manier kunnen intuïtievere antwoorden geëliciteerd worden. Een analyse van reactietijden kan bovendien extra waardevolle informatie bieden. 


\subsection{Spontane metacommunicatie en imitatiedata}

Saillantie kan niet enkel via expliciete bevraging blootgelegd worden, maar ook door spontane metacommunicatie over taal en de maatschappelijke omgang met taalvarianten te bestuderen. Worden bepaalde taalvarianten ingezet om de spot te drijven met specifieke sprekersgroepen? Welke taalvarianten worden gestigmatiseerd in onder andere het onderwijs? Als een sprekersgroep in stileringsprocessen geïmiteerd wordt, welke varianten worden dan gebruikt? Die laatste vraag vormde het vertrekpunt voor het onderzoek van Durham $(2015,2016)$, die naging hoe Twitteraars online een Welsh accent trachten te imiteren. Een dergelijke benadering sluit duidelijk aan bij de derde 'golf van sociolinguïstische studies (cf. Eckert 2012), waarin de benadering van saillantie als binaire eigenschap steeds meer vervangen wordt door benaderingen waarin de sociale betekenis van een variant (bijvoorbeeld als index van prestige of integriteit) centraal staat. Die betekenis zou allerminst stabiel zijn, maar veeleer continu geherdefinieerd worden in sociaal-semiotische processen (Campbell-Kibler 2011). Zo'n aanpak vinden we in Vlaanderen ook in het onderzoek van Jaspers \& Mercelis (2015) naar het gebruik van 'Illegaal Nederlands', al koppelen de onderzoekers hun resultaten niet aan saillantie. Dat jongeren van Marokkaanse herkomst vaak bewust blijken over te schakelen van hun doordeweekse Nederlandse naar karikaturale vormen van 'Illegaal Nederlands', kan ons immers leren welke kenmerken van dat 'Illegaal Nederlands' saillant zijn. Op die manier kan onderzoek naar taalstilering ook veel inzicht bieden in de saillantie van verschillende taalkenmerken. Een nadeel van dergelijk onderzoek is dat spontane dialectimitatie of bewuste taalstilering relatief zeldzaam zijn in spontaan taalgebruik, wat het saillantie-onderzoek kan bemoeilijken. Daarom wordt in saillantie-onderzoek soms met opgezette dialectimitatie-experimenten gewerkt, waarbij informanten gevraagd wordt een specifiek dialect of een specifieke sprekersgroep te imiteren (cf. Segerup 1999, Markham 1999, Evans 2002). Op die manier kunnen op korte tijd voldoende data verzameld worden die een indicatie bieden van de graad van saillantie van taalkenmerken (Trudgill 1986: 14). Een nadeel van zowel spontane als geëliciteerde imitaties is wel dat er een verschil is tussen bewustzijn van taalkenmerken enerzijds en de vaardigheid om dat kenmerk te kunnen nabootsen anderzijds. Een taalgebruiker mag zich wel bewust zijn van een taalvariant, dat betekent niet dat die ook automatisch in staat is dat kenmerk te imiteren. Op die manier kan opnieuw belangrijke informatie over saillantie verloren gaan. 


\subsection{Verschriftelijking}

Nauw gerelateerd met Durhams twitteronderzoek naar dialectimitatie is Schirmunski's verschriftelijkingscriterium (1928/1929, 1930). Schirmunski $(1928 / 1929,1930)$ gaat er immers van uit dat primaire (= saillante) kenmerken getypeerd worden door lekenverschriftelijking, wat dan ook als criterium kan dienen voor saillantie-onderzoek. Lenz (2003) bijvoorbeeld ging na welke van de onderzochte dialectvarianten in het Wittlicher Wörterbuch 'verschriftelijkt' worden, om zo inzicht te krijgen in hun saillantie (cf. ook Auer 2014: 16). Veel hangt bij verschriftelijking natuurlijk af van de mogelijkheid van het schriftsysteem, zo benadrukt ook Lenz (2010: 103), waardoor aanvulling met andere types saillantiedata noodzakelijk is om tot een volledig beeld te komen.

\subsection{Hypervormen}

Een vierde manier waarop saillantie gedetecteerd kan worden, is via de studie van hypercorrecties en hyperdialectismen (Hickey 2000, Lenz 2010), i.e. respectievelijk 'fouten' tegen de standaardtaal of tegen het dialect die gemaakt worden doordat taalgebruikers krampachtig proberen een dialect- of standaardtaal'fout' te vermijden (Lenz 2004). In West- en OostVlaanderen is een vaak voorkomende hypercorrectie bijvoorbeeld dat sprekers in een poging om hun / $/$ /-laryngalisering te onderdrukken ook een stemhebbende $[\mathrm{y}]$ realiseren in contexten waar de standaardtaal normaal een $[\mathrm{h}]$ vraagt. Hyperdialectismen daarentegen treffen we aan wanneer taalgebruikers met een gebrekkige dialectcompetentie toch trachten dialect te spreken en daarbij dialectkenmerken projecteren op vormen waarop die eigenlijk niet van toepassing zijn. Bijvoorbeeld: in het Maldegemse dialect wordt het AN /œy/ gerealiseerd als /ø:/ behalve in het woord kuiken, waar het normaal het foneem /i:/ heeft (Rys \& De Valck 2010: 536). Als een standaardtaalspreker het Maldegemse dialect poogt te spreken en daarbij het woord kuiken realiseert met het foneem /ø:/, dan spreken we van een hyperdialectisme. Dergelijke hypervormen wijzen erop dat de taalgebruikers zich vrij bewust is van het taalkenmerk in kwestie. Ook hier geldt echter weer dat hypervormen niet heel frequent voorkomen ${ }^{3}$, waardoor het niet altijd even evident is om op basis van die vormen saillantie te bestuderen. Bovendien kunnen hyperdialectismen enkel voorkomen bij niet-productieve taalkenmerken.

3 Cfr. Rys (2007) die vaststelde dat kinderen die het dialect 'secundair' verwerven bij een woordlijstoefening maar in $8 \%$ van de 13.824 bestudeerde tokens hyperdialectismen realiseren. 


\section{5 (Zelf)correcties}

Tot slot kunnen ook zelfcorrecties en corrigerende opmerkingen bij het taalgebruik van anderen duidelijke indicatoren zijn van saillantie. Auer (2014: 9) geeft het voorbeeld van een jongere MV, die het Duits van zijn vriend IL expliciet corrigeert tijdens een interview:

(2) IL ja nee, mein Thema war, Planung einer Halloween Party Int hm hm

IL isch hatte... 'd isch hatte... die Abschitte-

MV ich, nicht isch

IL ja. ich ich hatte Abschnitte... 'd äh Halloween Geschichte? und Halloween in Amerika.

IL ja nee, mijn thema was de planning van een halloweenfeestje. Int hm hm

IL ik (gerealiseerd als isch) heb het onderdeel... MV ich... niet isch.

IL ja. Ik... ik heb het onderdeel... de geschiedenis van Halloween? En Halloween in Amerika.

Een dergelijke passage toont duidelijk dat de coronalisering van ich zeer saillant is voor de jongere in kwestie. Op dezelfde manier kunnen ook zelfcorrecties op saillantie wijzen. Bij zowel correcties als zelfcorrecties geldt echter net als bij hypervormen en spontane metacommunicatie dat ze niet heel frequent voorkomen, waardoor ze moeilijk toelaten saillantie systematisch te bestuderen.

\subsection{Een multimethodologische aanpak}

De bovenstaande bespreking toont aan dat saillantie op verschillende manieren gedetecteerd kan worden, maar dat iedere methode zijn voor- en nadelen heeft. Om die reden is het aangewezen bij een studie naar saillantie verschillende methodes te combineren. Een dergelijke combinatie vinden we bij Purschke (2010). Hij liet niet-Hessische sprekers een Hessisch dialect/ accent nabootsen, waarbij de informanten zoveel mogelijk kenmerken moesten imiteren. Dat gebeurde in twee contexten: een voorbereide tekst die de informanten luidop moesten lezen en een context van spontaan taalgebruik. Nadien vergeleek hij de imitatiefragmenten met geintendeerde standaardtaalfragmenten van moedertaalsprekers van het Hessische dialect. Tot slot werden de imitatie- en geïntendeerde standaardtaalfragmenten voorgelegd aan zowel taalgebruikers met het Hessische dialect als moe- 
dertaal als aan informanten uit andere dialectgebieden. Door hen de fragmenten te laten beoordelen op authenticiteit, herkomst en afwijking van de standaardtaal was Purschke (2010) in staat een diepgaander inzicht te verwerven in de saillantie van verschillende Hessische kenmerken.

\section{$3 \quad$ Verklarende factoren}

Saillantie detecteren kan dus wel degelijk op een non-circulaire manier. De methodes die hierboven werden besproken, hebben echter een grote beperking: ze tonen wel of een kenmerk al dan niet saillant is, maar verklaren niet waaróm dat zo is (Auer, Barden \& Großkopf 1998: 165). Kerswill \& Williams (2002) benadrukken dat saillantie gedetermineerd wordt door een complexe set van factoren: niet enkel linguïstische factoren, maar ook extra-linguïstische zoals cognitieve, pragmatische, interactionele, sociopsychologische en socio-demografische factoren liggen aan de basis van saillantie. Hinskens, Auer \& Kerswill (2005: 45) stellen dan ook dat het praktisch gezien onmogelijk is om saillantieniveaus te voorspellen, al kan post-hoc argumentatie veel inzicht brengen. Wanneer we met behulp van bovenbeschreven technieken voor een arsenaal aan taalkenmerken hebben nagegaan of ze al dan niet saillant zijn, kunnen we op zoek gaan naar de eigenschappen van die taalkenmerken die hun saillantie kunnen verklaren. Die factoren worden beter niet ingezet om saillantie te detecteren, aangezien ze vaak interageren en onderling concurreren, en het met de huidige kennis moeilijk te bepalen is welke factor bij welk kenmerk de doorslag zal geven. Om die reden is het aangewezen bij empirisch onderzoek saillantie enkel te detecteren op basis van de pure verschijningsvorm (cf. §2), en niet door een beroep te doen op verklarende factoren. In wat volgt, bespreken we de verschillende verklarende factoren die in het werk rond saillantie opduiken.

\subsection{Fonetische afstand}

Een eerste factor die vaak als saillantie-inducerend gezien wordt, is de fonetische afstand tussen varianten. Zo menen Trudgill (1986) en Schirmunski (1930) dat radicaal fonetisch verschillende varianten er vaak voor zorgen dat een variabele saillant wordt. Die factor is echter niet onproblematisch. Auer et al. (1998) merken bijvoorbeeld op dat het criterium moeilijk operationaliseerbaar is in empirisch onderzoek. Volgens hen is het wel (ondanks de nodige moeilijkheden) mogelijk om articulatorische afstand te meten binnen één continue variabele, maar is vergelijking tussen ver- 
schillende variabelen praktisch onmogelijk (Auer, Barden \& Großkopf 1998: 170). Zij geven volgend voorbeeld:

$[T]$ he difference between the vernacular and the standard form may be said to be less for the pair USV [Upper Saxonian Vernacular, P.V. \& A.S.G.] [zp:gn,] vs. std. [za:gn, than for the pair USV [zo:gn, ] vs. std. [za:gn, ], since the phonetic difference on the non-round/round continuum of the low vowel is less in the first than it is in the second case. We may also say that the difference between the USV vernacular form [zb:xn] and std. [za:gn, is greater than that between USV [zp:gn, ] and std. [za:gn, ], for in the first case, two variables are involved - $(A:)$ and $(G)$ - while only one is involved in the second case. But according to which criteria should we judge and compare the objective articulatory [...] differences between the pairs [zo:gn, ]/ $[z a: g n$,$] and [z a: x n] /[z a: g n]$, e.g. differences within the variables $(A:)$ and $(G)$ in their strong vernacular realization?

Auer et al. (1998) beslissen dan ook om de factor buiten beschouwing te laten. Kerswill \& Williams (2002) echter nemen fonetische afstand wel degelijk op in hun onderzoek. Zij baseren zich op het werk van Rosner \& Pickering (1994) om 'just noticeable differences' te berekenen tussen vocalen en gaan dan na wat het effect is van die verschillen op de saillantie van een variant. Zij stelden echter vast dat die minimale fonetische verschillen niet kunnen helpen voorspellen of een bepaald klinkerverschil ook saillant zal zijn of niet.

\subsection{Fonologisch contrast}

Een tweede factor die vaak in saillantie-onderzoek aan bod komt, is fonologisch contrast (cf. Trudgill 1986). Als de varianten van een variabele te maken hebben met het al dan niet behouden van een fonologisch contrast (doordat bijvoorbeeld in regionale omgangstaal een fonologisch contrast uit de standaardtaal geneutraliseerd wordt), dan zou de variabele saillanter zijn dan een variabele waarbij de varianten losstaan van fonologische contrasten. Ook deze factor is allesbehalve onproblematisch. Auer et al. (1998: 166) merken op dat dit 'phonemicity criterion' een heel theoretisch construct is, dat ook weer moeilijk toe te passen is in empirisch onderzoek. Immers, 'what counts as 'phonemic' will be answered very differently in the various schools of phonology' (Auer, Barden \& Großkopf 1998: 166). Toch probeerden zij het te operationaliseren, maar stelden daarbij vast dat de phonemicity irrelevant was voor de saillantie van een kenmerk: de aanwezigheid van een contrast bleek geen garantie te zijn voor saillantie. Dat bleek ook uit het onderzoek van Kerswill \& Williams (2002). 


\subsection{Lexicalisatie}

Een criterium dat in vele werken rond saillantie aan bod komt, is lexicalisatie. Een kenmerk is gelexicaliseerd wanneer het exclusief voorkomt in specifieke lexicale items, terwijl het nooit voorkomt in andere lexemen in dezelfde fonologische context (Auer, Barden \& Großkopf 1998: 172-173). Bij lexicalisering is de vraag dus of het voorkomen van een kenmerk lexicaal dan wel structureel gedetermineerd is. Een duidelijk gelexicaliseerd kenmerk is de realisatie van zachtlange oo als [ø] in de Vlaamse dialecten. Dat kenmerk is immers sterk woordafhankelijk - het komt voor in zoon maar niet in toon - en valt niet door een structurele regel te beschrijven. Gelexicaliseerde kenmerken zijn volgens Schirmunski (1930) saillanter dan niet-gelexicaliseerde kenmerken, omdat ze minder voorspelbaar zijn. Auer et al. (1998: 172-173) observeren wel dat lexicalisatie er vaak voor zorgt dat saillante kenmerken stabieler worden, wat op de complexe relatie tussen saillantie en veranderingsgevoeligheid wijst.

\subsection{Frequentie}

Gerelateerd met lexicalisering is het idee dat er een recht evenredige relatie bestaat tussen de frequentie van een variant en zijn saillantie (cf. ook Bardovi-Harlig 1987). Kerswill \& Williams (2002) stellen echter vast dat ook laagfrequente varianten sterk saillant kunnen zijn en problematiseren de link tussen frequentie en saillantie (cf. ook Rácz 2012). Rys \& De Valck (2010) merken bovendien op dat ook typefrequentie, i.e. de hoeveelheid types, unieke vormen van een woord, waarin een patroon kan voorkomen, aandacht dient te krijgen in onderzoek naar taalverandering. Zij stelden immers vast dat kenmerken met een hoge typefrequentie significant vaker overgegeneraliseerd worden dan kenmerken met een lagere typefrequentie en dat het ook die kenmerken zijn die bij specifieke types dialectverandering gevoelig zijn voor verandering. Over de relatie tussen typefrequentie en saillantie is echter weinig geweten.

\subsection{Taaldomein/taalcomponent}

Een andere interessante, maar relatief onderbelichte factor in het saillantie-concept is het taaldomein waar een taalkenmerk toe gerekend kan worden. Interessant hierbij is Van Bree (2000, 1990), die erop wijst dat taalgebruikers zich niet van alle taaldomeinen of taalcomponenten even bewust zijn. Daarbij zouden taalgebruikers zich relatief onbewust zijn van fonetiek, semantiek en syntaxis en relatief bewust van primaire woordenschat, afleidings- en samenstellingsprocedés. Taeldeman (2009:367) stelt in dezelfde lijn dat syntactische elementen abstracter (en meer structureel 
ingebed) zijn dan lexicale items, waardoor ze ook minder saillant zijn (cf. Lybaert 2014, maar zie Kleene te verschijnen voor een andere visie). Van Bree (1990: 204) benadrukt wel dat er binnen de verschillende taaldomeinen nog variatie kan voorkomen. Zo blijken zijn Twentse informanten zich weinig bewust te zijn van niet-standaardtalige constructies (bijv. ik heb de band lek in plaats van mijn band is lek) en functiewoorden, maar wel van niet-standaardtalige volgordeverschijnselen. Hij besluit dat 'globale uitspraken over taaldomeinen toch minder gemakkelijk zijn dan gesuggereerd is' (Van Bree 1990: 204).

\subsection{Geografische verspreiding}

Een minder problematische factor in saillantie-onderzoek is de geografische verspreiding van taalkenmerken. Traditioneel gaat men ervan uit dat wijdverbreide taalkenmerken minder saillant zijn dan taalkenmerken met een beperkter gebruiksgebied (Schirmunski 1930). Dat wordt ook bevestigd door het empirische onderzoek van Schwob (1969), Hinskens (1992), Van Bree (1992), Kerswill \& Williams (2002) en Lenz (2003).

\subsection{Contrast}

Een zevende factor, die onder andere Hickey (2000: 6), Auer (2014) en Kleene (te verschijnen: 19) vermelden als saillantie-inducerend, is systeemconformiteit of contrast: hoe ongewoner een kenmerk is voor een bepaalde variëteit of voor een spreker, hoe saillanter. Een vergelijkbare hypothese wordt naar voren gedragen door Ghyselen (2009). Zij stelde bij haar attitude-onderzoek in West-Vlaanderen vast dat haar informanten negatiever staan tegenover standaardtalige fragmenten met enkel niet-standaardtalige lidwoorden dan tegenover tussentalige fragmenten en linkt dat resultaat aan het artificiële karakter van dergelijke gemanipuleerde fragmenten: doordat de tussentalige lidwoorden niet vergezeld zijn van andere nietstandaardtalige kenmerken waarmee ze doorgaans voorkomen, vallen ze meer op. De al besproken factor 'geografische verspreiding' kan gelinkt worden aan de factor contrast: wanneer een variant regionaal wijdverbreid is, impliceert dat dat taalgebruikers weinig met concurrerende varianten in aanraking komen; die beperkte contrastwerking kan de lage graad van saillantie van wijdverbreide kenmerken verklaren (cf. ook Auer 2014: 13). Die hypothese wijst duidelijk aan dat saillantie geen inherente eigenschap is van een taalvariant, maar door spreker- en contextgebonden factoren wordt beïnvloed. 


\subsection{Maatschappelijke normen}

Volgens Auer (2014) en Kleene (te verschijnen: 18) kunnen ook maatschappelijke waarde-oordelen en stereotypes kenmerken saillant maken. Kleene (te verschijnen) geeft het voorbeeld van de tun-parafrase (bijvoorbeeld in de zin wenn du schlafen tätst), die door zijn stigmatisatie in het Duitse taalgebied het hoogst zou scoren op saillantietests. Bij deze factor kunnen we ons echter afvragen in welke mate de stigmatisatie of stereotypisering een oorzaak, dan wel een gevolg van saillantie is. Auer (2014: 14) pleit er expliciet voor stereotypisering als oorzaak van saillantie te beschouwen, maar het lijkt ons adequater om van een wisselwerking uit te gaan: wanneer een kenmerk saillant is, kan dat het voorwerp worden van stereotypisering, maar die stereotypisering zorgt er tegelijkertijd voor dat het kenmerk nog saillanter wordt.

\section{$4 \quad$ Case-study}

\subsection{Opzet}

In 2014 werd door de eerste auteur van dit artikel een saillantie-onderzoek opgezet waaraan 28 Brabantse en 28 West-Vlaamse jongeren tussen 18 en 25 jaar deelnamen. De Brabantse jongeren waren geboren en getogen in het dialectgebied Brabant; de West-Vlaamse informanten waren allemaal uit het westelijk West-Vlaamse dialectgebied afkomstig. Evenveel mannen als vrouwen namen deel aan het onderzoek, dat als doel had (1) de saillantie van niet-standaardtalige taalkenmerken bloot te leggen met een combinatie van technieken, (2) inzicht te verwerven in de correlatie tussen saillantie en de factoren die in paragraaf 3 werden besproken en (3) het nut van dialectimitatie-experimenten bij saillantie-onderzoek te testen. Imitatie-onderzoek is in het Nederlandse taalgebied immers grotendeels onbestaande, en het is dan ook de vraag of het ons meer kan leren dan bijvoorbeeld expliciete bevraging zoals die door Lybaert (2014) werd toegepast.

De informanten werden opgedeeld in 4 groepen: 2 Brabantse groepen (a en c) en 2 West-Vlaamse (groepen b en d) met telkens 14 informanten ( 7 mannen en 7 vrouwen). Groepen a en b werkten mee aan fase 1 van het onderzoek; groepen c en d aan fase 2 (cf. Tabel 1$)$. In de eerste fase van het onderzoek werden aan de Brabantse informanten van groep a 43 standaardtalige zinnen (op papier) voorgelegd, die ze in 'een West-Vlaams dialect' moesten trachten te realiseren. De opgavezinnen werden geselecteerd uit de Reeks Nederlandse Dialectatlassen (RND), en werden zo ge- 
kozen dat ze voldoende taalkenmerken bevatten die zich leenden tot 'verwestvlaamsing' (onder andere diftongen, velaire [y]-fricatieven, woordenschat en diminutieven). Na de imitatietest (testcomponent 1 in Tabel 1) volgde een interview waarin de informanten gevraagd werd waarop ze hadden gelet bij het imiteren en wat hun in het algemeen opvalt als ze een West-Vlaming horen spreken (testcomponent 3). Aan de West-Vlamingen van groep b werd in fase 1 gevraagd 43 dialectzinnen te beluisteren en die een voor een om te zetten in 'standaardtaal zoals die tijdens de journaals gesproken werd' ${ }^{4}$ (testcomponent 2). Daarna werd hun in een interview ook gevraagd op welke taalkenmerken ze hadden proberen te letten (testcomponent 3). Belangrijk bij fase 1 is dat we geen uitspraken doen over saillantie op basis van de productiedata van de West-Vlamingen, aangezien dat tot circulariteit leidt. Wanneer saillantie immers gedetecteerd wordt op basis van productiedata, kunnen we moeilijk saillantie inroepen als verklarend concept om productiepatronen te verklaren (cf. §1). Testcomponent 2 diende enkel om opnames te verzamelen die in fase 2 als stimuli konden dienen.

Tabel 1 Overzicht testcomponenten

\begin{tabular}{|c|c|c|c|}
\hline & Testcomponent & Informantengroep & $\begin{array}{l}\text { Regionale herkomst } \\
\text { informanten }\end{array}$ \\
\hline \multirow[t]{4}{*}{ Fase 1} & 1. Dialectimitatie & Groep a $(n=14)$ & Brabant \\
\hline & 2. Standaardtaaltest & Groep b $(n=14)$ & West-Vlaanderen \\
\hline & 3. Expliciete bevraging zonder stimuli & Groep a $(n=14)$ & Brabant \\
\hline & & Groep b $(n=14)$ & West-Vlaanderen \\
\hline \multirow[t]{4}{*}{ Fase 2} & 4. Expliciete bevraging met imitatiedata als & Groep c $(n=14)$ & Brabant \\
\hline & stimuli & Groep d $(n=14)$ & West-Vlaanderen \\
\hline & 5. Expliciete bevraging met geïntendeerde & Groep c ( $n=14)$ & Brabant \\
\hline & standaardtaal als stimuli & Groep d ( $n=14)$ & West-Vlaanderen \\
\hline
\end{tabular}

In de tweede fase van het onderzoek lieten we een deel van de verzamelde opnames, nl. 15 zinnen uit het dialectimitatiemateriaal en 12 zinnen uit de geïntendeerde standaardtaal van de West-Vlamingen, horen aan informantengroepen c en d (testcomponenten 4 en 5). Naar analogie van Purschke (2010) werden de informanten gevraagd de stimuli te lokaliseren en op authenticiteit te beoordelen, met daarbij de expliciete instructie te verwijzen naar specifieke kenmerken in het stimulusmateriaal. Dat gebeurde

4 Deze vrij precieze formulering werden gekozen om te verzekeren dat alle informanten een vergelijkbare doelvariëteit voor ogen zouden hebben tijdens de tests (cf. Lenz 2003: 59-6o). 
tijdens mondelinge een-op-eeninterviews met de onderzoeker. De imitatiestimuli (15 zinnen) werden zo geselecteerd dat er zowel relatief geslaagde als minder geslaagde imitaties aan bod kwamen en dat ze ook lexicale, fonologische en morfo-syntactische dialectkenmerken bevatten. Bij de selectie van de standaardtaalstimuli (12 zinnen) werden zowel zinnen met als zonder duidelijke afwijkingen van de Belgisch-Nederlandse standaardtaalnorm gekozen en zorgden we eveneens voor zowel lexicale, fonologische als morfo-syntactische niet-standaardtalige kenmerken. De imitatie- en standaardtaalstimuli werden door elkaar aangeboden.

\subsection{Resultaten}

\section{Saillante kenmerken van het West-Vlaamse dialect}

Tabel 2 geeft een overzicht van alle West-Vlaamse dialectkenmerken in de loop van het onderzoek (alle testcomponenten samen) minimaal vijf keer geïmiteerd of opgemerkt werden. We focussen in dit artikel om redenen van beknoptheid enkel op kenmerken van het West-Vlaamse dialect/intermediaire taalgebruik die in de testcomponenten naar voren kwamen, niet op Brabantismen of nieuwvormingen die toevallig in de imitaties slopen. Voor elk kenmerk gingen we per testsetting na hoeveel informanten het kenmerk in kwestie imiteerden of opmerkten. De som van die aantallen, weergegeven in kolom 3 van Tabel 2, kan als indicatie gelden voor de saillantie van dat kenmerk. Uiteraard zijn die cijfers sterk beïnvloed door de samenstelling van het stimulusmateriaal; het is immers vrij evident dat kenmerken die niet of amper in het stimulusmateriaal voorkwamen minder frequent genoemd/opgemerkt werden dan kenmerken die verschillende keren voorkwamen. Om die reden wordt in kolommen 4 en 5 van Tabel 2 weergegeven hoe vaak de kenmerken in het stimulusmateriaal voorkwamen. Kolom 6 toont 'genormaliseerde cijfers' waarbij we het aantal keer dat de informanten een kenmerk opmerkten of imiteerden delen door de frequentie van de kenmerken in het stimulusmateriaal (imitatieén standaardtaalstimuli). Als een kenmerk niet voorkwam in het stimulusmateriaal, werd in kolom 6 de absolute frequentie genoteerd.

Interessant is dat de respondenten in testcomponenten 5 en 6 soms ook kenmerken opmerkten die eigenlijk niet in het stimulusmateriaal voorkwamen. Een aantal Brabantse informanten beoordeelden het vocalisme in testcomponent 5 bijvoorbeeld vaak als 'te open', ook wanneer de voca- 
len standaardtalig gerealiseerd werden. ${ }^{5}$ Hierbij speelt zonder twijfel dat de Brabantse dialecten voor de korte vocalen een gesloten vocaalsysteem hebben, waardoor ook het standaardtaalsysteem - dat op het vlak van korte vocalen een intermediaire positie inneemt tussen het Brabantse en het West-Vlaamse systeem - in de perceptie van Brabanders vrij 'open' aanvoelt. Verschillende West-Vlaamse informanten percipieerden in testcomponent $5 t$-deleties, $h$-deleties of hypercorrecte [y]'s wanneer die eigenlijk niet gerealiseerd werden in de stimuli. Die observatie kan niet verklaard worden door contrastwerking met het eigen taalgebruik; een verklaring moet wellicht gezocht worden in de manier waarop taalgebruikers perceptietaken uitvoeren. Zoals Preston (2010b: 3) ook benadrukt, doen respondenten tijdens perceptie-experimenten een beroep op hun talige voorkennis, waarbij ze zich onder andere laten beïnvloeden door 'ingebakken' overtuigingen over taalvariatie. In het geval van ons experiment is het waarschijnlijk dat de West-Vlaamse informanten bij het horen van specifieke West-Vlaamse accent- of dialectkenmerken meteen ook andere kenmerken verwachten en die kenmerken dan ook percipiëren wanneer ze er eigenlijk niet zijn.

Tabel 2 Opgemerkte/geïmiteerde West-Vlaamse dialectkenmerken

\begin{tabular}{|c|c|c|c|c|c|}
\hline Kenmerk & Voorbeeld & $\begin{array}{l}\text { Aantal keer op- } \\
\text { gemerkt/geïm- } \\
\text { iteerd }\end{array}$ & $\begin{array}{l}\text { Frequentie in } \\
\text { imitatiestimuli }\end{array}$ & $\begin{array}{l}\text { Frequentie in } \\
\text { stimuli met ge- } \\
\text { ïntendeerde } \\
\text { standaardtaal }\end{array}$ & $\begin{array}{l}\text { Aantal keer op- } \\
\text { gemerkt/geïm- } \\
\text { iteerd (genorma- } \\
\text { liseerd) }\end{array}$ \\
\hline $\begin{array}{l}\text { Laryngalisering van } \\
\text { [४] }\end{array}$ & $\begin{array}{l}\text { [h]oed [h]edaan } \\
\text { ('goed gedaan') }\end{array}$ & 64 & 4 & 4 & 8,0 \\
\hline Sjwa-deletie & [vutn] ('voeten') & 57 & 4 & 2 & 9,5 \\
\hline $\begin{array}{l}\text { Niet-standaardtalige } \\
\text { woordenschat }\end{array}$ & wuf ('vrouw') & 46 & 1 & 1 & 23,0 \\
\hline ST [a:] $\rightarrow$ DIA [৩:] & [wo:tər] ('water') & 44 & 5 & 2 & 6,3 \\
\hline $\begin{array}{l}\text { Laryngalisering [x] (in } \\
\text { bv. zacht) }\end{array}$ & [zohtə] ('zacht') & 41 & 1 & 3 & 10,3 \\
\hline ST [Ei] $\rightarrow$ DIA [i:] & [gi] ('gij') & 39 & 2 & 0 & 19,5 \\
\hline Open [I] & [Iָ $]$ ('ik') & 39 & 5 & 1 & 6,5 \\
\hline $\begin{array}{l}\text { Niet-standaardtalige } \\
\text { pronomina }\end{array}$ & $\begin{array}{l}\text { gidder ('jullie'), gie } \\
\text { ('jij') }\end{array}$ & 39 & 4 & 0 & 9,8 \\
\hline Samentrekking & z'ebn ('ze hebben') & 37 & 4 & 0 & 9,3 \\
\hline
\end{tabular}

5 Het vocalisme in de opnames werd door drie neerlandici - met uiteenlopende regionale achtergronden - beoordeeld op standaardtaligheid. 


\begin{tabular}{|c|c|c|c|c|c|}
\hline Kenmerk & Voorbeeld & $\begin{array}{l}\text { Aantal keer op- } \\
\text { gemerkt/geïm- } \\
\text { iteerd }\end{array}$ & $\begin{array}{l}\text { Frequentie in } \\
\text { imitatiestimuli }\end{array}$ & $\begin{array}{l}\text { Frequentie in } \\
\text { stimuli met ge- } \\
\text { ïntendeerde } \\
\text { standaardtaal }\end{array}$ & $\begin{array}{l}\text { Aantal keer op- } \\
\text { gemerkt/geïm- } \\
\text { iteerd (genorma- } \\
\text { liseerd) }\end{array}$ \\
\hline Niet-suffigale sjwa & $\begin{array}{l}\text { bedde ('bed'), kele } \\
\text { ('keel') }\end{array}$ & 34 & 3 & 0 & 11,3 \\
\hline Procope [h] & [e:məl] ('hemel') & 32 & 4 & 0 & 8,0 \\
\hline ST [0:] $\rightarrow$ DIA [ø] & [zøn] ('zoon') & 32 & 6 & 0 & 5,3 \\
\hline Open $[\varepsilon]$ & [bع̨t] ('bed') & 31 & 1 & 2 & 10,3 \\
\hline ST [sX] $\rightarrow$ DIA [sk] & [skIp] ('schip') & 31 & 3 & 0 & 10,3 \\
\hline $\begin{array}{l}\text { Gesloten realisatie } \\
\text { diftongen }{ }^{6}\end{array}$ & [reip] ('rijp') & 30 & 2 & 6 & 3,8 \\
\hline ST [œ.y] $\rightarrow$ DIA [y] & [tys] ('thuis') & 22 & 1 & 0 & 22,0 \\
\hline ST [O.u] $\rightarrow$ DIA [u] & [kut] ('koud') & 21 & 2 & 0 & 10,5 \\
\hline Meervoudssuffix -s & Kinders ('kinderen') & 21 & 1 & 0 & 21,0 \\
\hline $\begin{array}{l}\text { Niet-standaardtalige } \\
\text { lidwoordvormen }\end{array}$ & ne vent ('een vent') & 19 & 4 & 0 & 4,8 \\
\hline T-apocope & da mens ('dat mens') & 19 & 2 & 0 & 9,5 \\
\hline ST [a:] $\rightarrow$ DIA [ø] & [ørbuk] ('haar boek') & 18 & 2 & 0 & 9,0 \\
\hline Hypercorrecte $[\gamma]$ & $\begin{array}{l}\text { [ye:lyut] ('heel } \\
\text { goed') }\end{array}$ & 18 & 1 & 0 & 18,0 \\
\hline ST [0] $\rightarrow$ DIA [ᄉ] & [^p] ('op') & 17 & 2 & 0 & 8,5 \\
\hline ST [n] $\rightarrow$ DIA [nk] & [kønink] ('koning') & 16 & 1 & 0 & 16,0 \\
\hline $\begin{array}{l}\text { Realisatie scherplange } \\
\text { [e:] als tweeklank }\end{array}$ & [breət] ('breed') & 14 & 1 & 0 & 14,0 \\
\hline $\begin{array}{l}\text { Diminutieven met ke- } \\
\text { suffix }\end{array}$ & bloemke ('bloempje') & 14 & 1 & 0 & 14,0 \\
\hline ST [a] $\rightarrow$ DIA [o] & [วf] ('af') & 10 & 0 & 0 & 10,0 \\
\hline ST $[\varepsilon i] \rightarrow$ DIA $[\Lambda]$ & [blıvn] ('blijven') & 8 & 0 & 0 & 8,0 \\
\hline $\begin{array}{l}\text { Klinkerverkorting voor } \\
\text { consonantclusters }\end{array}$ & [həwIst] ('geweest') & 8 & 1 & 0 & 8,0 \\
\hline Palatalisatie -je & [mantfə] ('mandje') & 8 & 0 & 1 & 8,0 \\
\hline Open $[\Lambda]$ & [p^t] ('put') & 8 & 2 & 2 & 2,0 \\
\hline $\begin{array}{l}\text { Niet-standaardtalige } \\
\text { verbuiging adjectief }\end{array}$ & $\begin{array}{l}\text { ne warmen avond } \\
\text { ('een warme avond') }\end{array}$ & 8 & 0 & 0 & 8,0 \\
\hline ST [عi] $\rightarrow$ DIA [i] & [tit] ('tijd') & 6 & 1 & 0 & 6,0 \\
\hline
\end{tabular}

6 De gesloten diftongering is in se geen dialectkenmerk, maar veeleer een substandaardkenmerk. In hun geïntendeerde standaardtaal realiseren West-Vlamingen het eerste element van tweeklanken vaak hoger dan we in de VRT-standaardtaal verwachten, naar analogie met de hoge klinkers in West-Vlaamse dialect (Rys \& Taeldeman 2007). 
Uit Tabel 2 blijkt dat er duidelijke variatie is in de saillantie van WestVlaamse dialectkenmerken. De laryngalisering van [8] prijkt - niet helemaal verrassend - bovenaan het lijstje van meest opgemerkte of geïmiteerde kenmerken. Onze data bevestigen duidelijk de status van [8]-laryngalisering als sjibbolet voor de West-Vlaming (cf. Devos \& Vandekerckhove 2005: 41). Andere saillante kenmerken zijn de deletie van sjwa en 'typisch West-Vlaamse woordenschat'. Kenmerken als niet-standaardtalige lidwoorden of de gesloten realisatie van diftongen blijken daarentegen minder saillant; die kenmerken kwamen relatief frequent in het stimulusmateriaal voor, maar werden niet vaak opgemerkt. In wat volgt, bestuderen we de data gedetailleerder. Eerst brengen we de variatie tussen testcomponenten in kaart, waarna we de percepties van Brabantse en West-Vlaamse respondenten met elkaar vergelijken.

\section{De impact van de testsetting}

In Tabel 3 wordt per kenmerk en per testcomponent weergegeven hoeveel percent van de informanten het kenmerk in kwestie opmerkte, gesorteerd volgens de deviatie tussen de verschillende testcomponenten. Uit die tabel blijkt onmiddellijk dat de percentages - die we als indicatief voor de saillantie van die kenmerken kunnen beschouwen - sterk afhankelijk zijn van de testsetting waarin de respondenten bevraagd werden. Zo zien we bijvoorbeeld dat bij expliciete bevraging zonder stimuli veel minder informanten een kenmerk opmerken dan bij bevraging met stimuli. Dat patroon is ook statistisch significant: globaal genomen blijken de informanten een kenmerk significant vaker op te merken bij expliciete bevraging met stimuli dan bij expliciete bevraging zonder stimuli $\left(\mathrm{X}^{2}, \mathrm{p}<0,001\right) .{ }^{7}$ Stimulusmateriaal geeft informanten duidelijk een houvast en maakt het makkelijker talige kennis te expliciteren. Dat betekent echter niet dat expliciete bevraging zonder stimuli achterwege gelaten mag worden in saillantiestudies; dat type bevraging leert immers - meer dan andere methodes - welke kenmerken als stereotypes fungeren in de taalgemeenschap. Uit ons onderzoek blijkt bijvoorbeeld duidelijk dat [y]-laryngalisering, sjwa-deletie en dialectische woordenschat stevig verankerd zitten als stereotypes in lekenpercepties van het West-Vlaamse dialect.

Tussen de dialectimitatiecontext en de expliciete bevraging met stimuli werden op globaal niveau geen significante verschillen aangetroffen ${ }^{8}$; bij

7 Bij de statistische analyses werden enkel de data meegenomen over kenmerken die ook effectief in het stimulusmateriaal voorkwamen.

8 De vergelijking werd enkel gemaakt voor de Brabantse data, aangezien de West-Vlamingen geen dialectimitatietest aflegden. 
de expliciete bevraging werden er evenveel kenmerken opgemerkt als er in de imitatiecontext geïmiteerd werden. Dat globale patroon gaat echter niet voor alle kenmerken op. Als we de testcomponenten per kenmerk vergelijken, dan kan vastgesteld worden dat een aantal kenmerken (zoals de open realisatie van $[\varepsilon]$, de hypercorrecte $g$ en de laryngalisering van $[\chi]$ ) significant vaker opgemerkt worden in het stimulusmateriaal dan dat ze geïmiteerd worden in de imitatietest (Fisher's Exact Test, $p$-waarden van respectievelijk 0,046, 0,013 en 0,018). Bij die kenmerken speelt wellicht dat het enige vaardigheid vergt om ze na te bootsen. Voor andere kenmerken troffen we dan weer het omgekeerde patroon aan, namelijk dat ze significant vaker geïmiteerd worden dan dat ze opgemerkt worden in het stimulusmateriaal. Dat was bijvoorbeeld het geval voor $h$-deletie, $t$-deletie of de $k e$-diminutieven (Fisher's Exact test, $p$-waarden van respectievelijk 0,006, 0,026 en 0,001). Het ligt echter voor de hand dat die kenmerken geïmiteerd werden omdat ze ook in de Brabantse dialecten (en tussentaal) endogeen zijn; de kenmerken zijn daarom niet noodzakelijk saillant voor de onderzochte Brabanders als kenmerken van het West-Vlaamse dialect. Bij die opmerking rijst de logische vraag of dialectimitatiedata dan eigenlijk nog nuttig zijn in saillantie-onderzoek, zeker wanneer we in rekening brengen wordt dat informanten ongeveer evenveel kenmerken opmerken bij expliciete bevraging met stimulusmateriaal, en dat sommige kenmerken, zoals de open realisatie van $[\varepsilon]$, om methodologische redenen onder de radar blijven in een imitatie-experiment. Bij die vraag mogen we o.i. de belangrijkste zwakte van bevraging met stimulimateriaal niet uit het oog verliezen, namelijk dat de resultaten ervan sterk gestuurd zijn door de samenstelling van de stimuli. Dat probleem is er niet bij een dialectimitatieexperiment, en het is volgens ons dan ook nog steeds waardevol beide methodes te combineren en de resultaten ervan te vergelijken. 
Tabel 3 Percentages respondenten per testcomponent die een kenmerk opmerken/imiteren; voor kenmerken die niet in het stimulusmateriaal voorkwamen in testcomponenten 4 en 5 worden - voor die testcomponenten - geen percentages weergegeven

\begin{tabular}{|c|c|c|c|c|c|}
\hline & Dialectimitatie & $\begin{array}{c}\text { Bevraging met } \\
\text { imitatiedata als } \\
\text { stimuli }\end{array}$ & $\begin{array}{l}\text { Bevraging met } \\
\text { geïntendeerde } \\
\text { ST als stimuli }\end{array}$ & $\begin{array}{l}\text { Bevraging zon- } \\
\text { der stimuli }\end{array}$ & StDev \\
\hline $\begin{array}{l}\text { Niet-standaardtalige lidwoord- } \\
\text { vormen }\end{array}$ & 92,9 & 17,9 & I & 0,0 & 49,3 \\
\hline t-aросоре & 92,9 & 14,3 & I & 3,6 & 48,8 \\
\hline Procope [h] & 100,0 & 53,6 & l & 7,1 & 46,4 \\
\hline niet-suffigale sjwa & 78,6 & 75,0 & I & 7,1 & 40,2 \\
\hline Pronomina & 92,9 & 75,0 & l & 17,9 & 39,2 \\
\hline ke-diminutieven & 71,4 & 14,3 & l & 0,0 & 37,8 \\
\hline$[0:]>[\varnothing]$ & 71,4 & 67,9 & 0,0 & 10,7 & 37,4 \\
\hline$[\mathrm{sx}]>[\mathrm{sk}]$ & 28,6 & 82,1 & 1 & 10,7 & 37,2 \\
\hline $\begin{array}{l}\text { Klinkerverkorting voor conso- } \\
\text { nantclusters }\end{array}$ & 71,4 & 25,0 & I & 0,0 & 36,2 \\
\hline Samentrekking & 92,9 & 53,6 & I & 25,0 & 34,1 \\
\hline Verbuiging adjectieven & 57,1 & 0,0 & I & 0,0 & 33,0 \\
\hline$[\varepsilon i]>[i:]$ & 71,4 & 82,1 & l & 21,4 & 32,4 \\
\hline [a:] > [ø] & 64,3 & 32,1 & l & 0,0 & 32,1 \\
\hline Woordenschat & 57,1 & 71,4 & 3,6 & 60,7 & 30,4 \\
\hline$[0 . u]>[u]$ & 28,6 & 60,7 & 1 & 0,0 & 30,4 \\
\hline [a:] > [o:] & 92,9 & 42,9 & 46,4 & 21,4 & 30,1 \\
\hline Laryngalisering $[x]$ & 35,7 & 32,1 & 82,1 & 14,3 & 28,9 \\
\hline s-meervoud & 50,0 & 50,0 & l & 0,0 & 28,9 \\
\hline$[0]>[\Lambda]$ & 57,1 & 32,1 & I & 0,0 & 28,6 \\
\hline$[œ . y]>$ [y] & 64,3 & 39,3 & l & 7,1 & 28,6 \\
\hline Open [I] & 78,6 & 53,6 & 17,9 & 28,6 & 27,1 \\
\hline$[\varepsilon i]>[\Lambda]$ & 42,9 & 1 & 1 & 7,1 & 25,3 \\
\hline$[n]>[n k]$ & 21,4 & 46,4 & l & 0,0 & 23,2 \\
\hline$[\mathrm{a}]>[\mathrm{o}]$ & 28,6 & l & I & 0,0 & 20,2 \\
\hline Scherplange ee & 42,9 & 25,0 & I & 3,6 & 19,7 \\
\hline Gesloten realisatie diftongen & 42,9 & 35,7 & 46,4 & 3,6 & 19,6 \\
\hline Hypercorrecte $[\gamma]$ & 7,1 & 39,3 & I & 14,3 & 16,9 \\
\hline Palatalisatie -je & 0,0 & 1 & 28,6 & 0,0 & 16,5 \\
\hline$[\varepsilon i]>[i]$ & 28,6 & 7,1 & 1 & 0,0 & 14,9 \\
\hline Open $[\varepsilon]$ & 14,3 & 39,3 & 42,9 & 21,4 & 13,8 \\
\hline Open $[\Lambda]$ & 21,4 & 0,0 & 17,9 & 0,0 & 11,4 \\
\hline Sjwa-deletie & 71,4 & 57,1 & 60,7 & 50,0 & 8,9 \\
\hline Laryngalisering van $[\gamma]$ & 71,4 & 60,7 & 57,1 & 75,0 & 8,5 \\
\hline
\end{tabular}


Een vergelijking van testcomponenten 4 en 5 (expliciete bevraging met respectievelijk imitatiedata en geïmiteerde standaardtaal als stimuli) levert geen eenduidige patronen op. Voor de kenmerken die in zowel de imitatiestimuli als de stimuli met geïntendeerde standaardtaal voorkwamen, vonden we enkel bij de laryngalisering van $[\chi]$, de open $[\mathrm{I}]$ en de nietstandaardtalige woordenschat een significant verschil tussen de twee contexten. De open [I] en de niet-standaardtalige woordenschat werden significant vaker opgemerkt in testcomponent 4 dan in 5 (Fisher's Exact Test, pwaarde van respectievelijk 0,011 en <0,001), wat logisch is aangezien die kenmerken duidelijker en frequenter aanwezig waren in de imitatiestimuli. De laryngalisering van $[\chi]$ kwam dan weer frequenter voor in het stimulusmateriaal van testcomponent 5 , wat verklaart waarom dat kenmerk significant vaker werd opgemerkt in die testsetting (Fisher's Exact Test, $\mathrm{p}<0,001)$.

\section{De impact van de regionale herkomst van de hoorder}

Een chi-kwadraatanalyse toont dat er op globaal niveau - wanneer we alle taalkenmerken samen bestuderen - geen significante verschillen zijn tussen Brabanders en West-Vlamingen in het aantal taalkenmerken opgemerkt bij de expliciete bevraging (met of zonder stimuli). ${ }^{9}$ Globale uitspraken over de impact van de regionale herkomst van de respondent kunnen dan ook moeilijk gedaan worden. Wanneer we de kenmerken individueel bestuderen (cf. Figuur 1), zijn er voor een aantal kenmerken wel significante verschillen tussen de Brabanders en West-Vlamingen. De gesloten realisatie van de tweeklanken en de open realisatie van [I] blijken Brabantse informanten bijvoorbeeld significant vaker op te merken dan West-Vlamingen (Fisher's Exact Test, p-waarden van respectievelijk 0,028 en <0,001). Met de terminologie van Lybaert (2014) kunnen we hier van heterosaillante kenmerken spreken, i.e. kenmerken die opvallen voor wie de kenmerken zelf niet kent in zijn of haar eigen taalgebruik. Sjwa-deletie daarentegen kunnen we autosaillant noemen, aangezien de West-Vlamingen dat kenmerk significant vaker bleken op te merken dan de Brabanders (Fisher's Exact Test, $\mathrm{p}<0,001$ ).

9 De imitatiedata werden niet meegenomen in de vergelijking aangezien de West-Vlamingen geen imitatietest aflegden. 


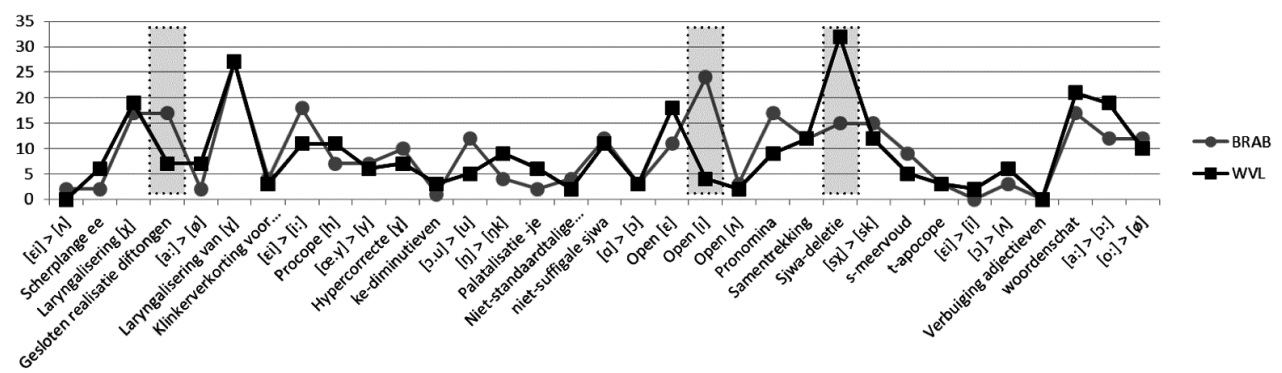

Figuur 1 Aantal respondenten die een kenmerk opmerken ${ }^{10}$ per regio; significante verschillen tussen Brabantse en West-Vlaamse respondenten zijn gemarkeerd in stippellijnen

De beschreven patronen onderschrijven het idee dat er een onderscheid gemaakt moet worden tussen Selbstwahrnehmung en Fremdwahrnehmung (Auer 2014: 17). Tegelijkertijd roepen ze een aantal vragen op. Waarom zijn sommige kenmerken bijvoorbeeld heterosaillant, andere autosaillant en nog andere disaillant, i.e. opvallend voor zowel taalgebruikers die de kenmerken zelf gebruiken als andere taalgebruikers? Wellicht speelt hier een combinatie van factoren. Systeemcontrast kan bijvoorbeeld ingeroepen worden om de heterosaillantie van de gesloten realisatie van de tweeklanken en de open realisatie van $[\mathrm{I}]$ te verklaren, terwijl correctiepraktijken in het onderwijs mogelijk kunnen verklaren waarom West-Vlamingen zich bewuster zijn van sjwa-deletie dan Brabanders. De mate waarin factoren als systeemcontrast en correctiepraktijken een rol spelen, varieert per kenmerk, wat kan verklaren waarom er variatie is tussen heterosaillante, autosaillante en disaillante kenmerken.

\section{Andere verklarende factoren}

Uit het bovenstaande blijkt dat systeemcontrast bij sommige kenmerken in saillantie resulteert. Er zijn echter nog tal van andere factoren die de saillantie van een kenmerk kunnen verklaren (cf. §3). In wat volgt, gaan we na in welke mate de factoren lexicalisatie, taaldomein, regionale verspreiding en frequentie in het stimulusmateriaal de variatie in saillantie tussen kenmerken kunnen verklaren. Tabel 4 biedt een overzicht van die factoren voor de taalkenmerken die in onze experimenten opgemerkt werden. Een kenmerk wordt als gelexicaliseerd beschouwd wanneer er in vergelijking

10 Op de $\mathrm{x}$-as wordt de som afgebeeld van de aantallen informanten die een kenmerk opmerkten in drie onderzoekssettings: de bevraging met imitatiestimuli, de bevraging met geïntendeerde standaardtaal als stimuli en de bevraging zonder stimuli. 
met de standaardtaal geen structurele regel geformuleerd kan worden (zie Ghyselen 2016: 321-322 voor een uitgebreidere bespreking van dit begrip). In tegenstelling tot in Tabel 2 focussen we in kolom 3 van Tabel 4 enkel op de cijfers uit onderzoeksfase 2 (= bevraging met en zonder stimuli). Door de Brabantse dialectimitatiedata buiten beschouwing te laten, vermijden we dat een overwicht aan Brabantse informanten het effect van andere factoren verhult of vertekent.

Tabel 4 Opgemerkte/geïmiteerde West-Vlaamse dialectkenmerken met informatie over de regionale verspreiding, eventuele lexicalisering en aard van die kenmerken

\begin{tabular}{|c|c|c|c|c|c|c|c|}
\hline \multicolumn{2}{|c|}{ Kenmerk } & \multirow{2}{*}{$\begin{array}{c}\text { Voorbeeld } \\
\text { [h]oed [h] } \\
\text { edaan ('goed } \\
\text { gedaan') }\end{array}$} & \multirow{2}{*}{$\begin{array}{c}\begin{array}{c}\text { Aantal keer } \\
\text { opgemerkt in } \\
\text { Fase } 2\end{array} \\
54\end{array}$} & \multirow{2}{*}{$\begin{array}{l}\text { Regionale } \\
\text { Versprei- } \\
\text { ding }^{11} \\
+++\end{array}$} & \multirow{2}{*}{$\begin{array}{c}\text { Gelexicali- } \\
\text { seerd? } \\
\text { Nee }\end{array}$} & \multirow{2}{*}{$\begin{array}{c}\begin{array}{c}\text { Type taalken- } \\
\text { merk }\end{array} \\
\text { Fonologie }\end{array}$} & \multirow{2}{*}{$\begin{array}{c}\begin{array}{c}\text { Frequentie in } \\
\text { stimulus- } \\
\text { materiaal }\end{array} \\
8\end{array}$} \\
\hline $\begin{array}{l}\text { Meest } \\
\text { opge- } \\
\text { merkt }\end{array}$ & $\begin{array}{l}\text { Laryngalisering } \\
\text { van }[\mathrm{\gamma}]\end{array}$ & & & & & & \\
\hline & Sjwa-deletie & $\begin{array}{l}\text { [vutṇ] ('voe- } \\
\text { ten') }\end{array}$ & 47 & +++ & Nee & Fonologie & 6 \\
\hline & $\begin{array}{l}\text { Niet-standaard- } \\
\text { talige woor- } \\
\text { denschat }\end{array}$ & wuf ('vrouw') & 38 & n.v.t. & n.v.t. & Woordenschat & 2 \\
\hline & $\begin{array}{l}\text { Laryngalisering } \\
\text { [x] (in bv. } \\
\text { zacht) }\end{array}$ & $\begin{array}{l}\text { [zohtə] } \\
\text { ('zacht') }\end{array}$ & 36 & +++ & Nee & Fonologie & 4 \\
\hline & $\begin{array}{l}\text { ST [a:] } \rightarrow \text { DIA } \\
\text { [0:] }\end{array}$ & $\begin{array}{l}\text { [wo:tər] } \\
\text { ('water') }\end{array}$ & 31 & ++ & Nee & Fonologie & 7 \\
\hline & $\begin{array}{l}\text { ST [Ei] } \rightarrow \text { DIA } \\
\text { [i:] }\end{array}$ & [gi] ('gij') & 29 & ++ & $\mathrm{Ja}$ & Fonologie & 2 \\
\hline & Open $[\varepsilon]$ & [bع̨t] ('bed') & 29 & +++ & Nee & Fonologie & 3 \\
\hline & Open [I] & [Iָk] ('ik') & 28 & +++ & Nee & Fonologie & 6 \\
\hline & $\begin{array}{l}\text { ST }[s X] \rightarrow \text { DIA } \\
{[s k]}\end{array}$ & [skIp] ('schip') & 27 & + & Nee & Fonologie & 3 \\
\hline & $\begin{array}{l}\text { Niet-standaard- } \\
\text { talige pronomi- } \\
\text { na }\end{array}$ & $\begin{array}{l}\text { gidder ('jullie'), } \\
\text { gie ('jij') }\end{array}$ & 26 & $\begin{array}{l}\text { pronomen-af- } \\
\text { hankelijk }\end{array}$ & n.v.t. & Morfo-syntaxis & 4 \\
\hline
\end{tabular}

11 Regionale verspreiding: $+=<$ West-Vlaams dialectgebied, $++=$ West-Vlaams dialectgebied, +++ $=$ West- en Oost-Vlaams, $++++=>$ West - en Oost-Vlaams, $+++++=$ West-Vlaams \& Brabants (maar niet Oost-Vlaams) 
DE DETECTIE VAN SAILLANTE TAALKENMERKEN

\begin{tabular}{|c|c|c|c|c|c|c|c|}
\hline Kenm & & Voorbeeld & Aantal keer & Regionale & Gelexicali- & Type taalken- & Frequentie in \\
\hline $\begin{array}{l}\text { Meest } \\
\text { opge- }\end{array}$ & $\begin{array}{l}\text { Gesloten reali- } \\
\text { satie diftongen }\end{array}$ & [reip] ('rijp') & 24 & ++ & Nee & Fonologie & 8 \\
\hline merkt & Samentrekking & $\begin{array}{l}\text { z'ebn ('ze heb- } \\
\text { ben') }\end{array}$ & 24 & ++++ & Nee & Morfo-syntaxis & 4 \\
\hline & $\begin{array}{l}\text { Niet-suffigale } \\
\text { sjwa }\end{array}$ & $\begin{array}{l}\text { bedde ('bed'), } \\
\text { kele ('keel') }\end{array}$ & 23 & +++ & $\mathrm{Ja}$ & $\begin{array}{c}\text { Fonologie/ } \\
\text { Morfo-syntaxis }\end{array}$ & 3 \\
\hline & $\begin{array}{l}\text { ST [0:] } \rightarrow \text { DIA } \\
{[\emptyset]}\end{array}$ & [zøn] ('zoon') & 22 & +++ & $\mathrm{Ja}$ & Fonologie & 6 \\
\hline & Procope [h] & $\begin{array}{l}\text { [e:məl] } \\
\text { ('hemel') }\end{array}$ & 18 & ++++ & Nee & Fonologie & 4 \\
\hline & $\begin{array}{l}\text { Hypercorrecte } \\
{[\text { [ ] }}\end{array}$ & $\begin{array}{l}\text { [ye:lyut] ('heel } \\
\text { goed') }\end{array}$ & 17 & +++ & Nee & Fonologie & 1 \\
\hline & $\begin{array}{l}\text { ST [O.u] } \rightarrow \text { DIA } \\
{[\mathrm{u}]}\end{array}$ & [kut] ('koud') & 17 & ++ & $\mathrm{Ja}$ & Fonologie & 2 \\
\hline & $\begin{array}{l}\text { Meervoudssuf- } \\
\text { fix }-\mathrm{s}\end{array}$ & $\begin{array}{l}\text { Kinders ('kinde- } \\
\text { ren') }\end{array}$ & 14 & $\begin{array}{c}\text { woordafhanke- } \\
\text { lijk }\end{array}$ & $\mathrm{Ja}$ & Morfo-syntaxis & 1 \\
\hline & $\begin{array}{l}\text { ST [œ.y] } \rightarrow \text { DIA } \\
\text { [y] }\end{array}$ & [tys] ('thuis') & 13 & ++ & $\mathrm{Ja}$ & Fonologie & 1 \\
\hline & $\begin{array}{l}\text { ST }[\eta] \rightarrow \text { DIA } \\
{[\eta \mathrm{k}]}\end{array}$ & $\begin{array}{l}\text { [kønink] ('ko- } \\
\text { ning') }\end{array}$ & 13 & ++++ & $\mathrm{Ja}$ & Fonologie & 1 \\
\hline & $\begin{array}{l}\text { ST [a:] } \rightarrow \text { DIA } \\
{[\varnothing]}\end{array}$ & $\begin{array}{l}\text { [ørbuk] ('haar } \\
\text { boek') }\end{array}$ & 9 & ++++ & $\mathrm{Ja}$ & Fonologie & 2 \\
\hline & $\begin{array}{l}\text { ST [O] } \rightarrow \text { DIA } \\
{[\Lambda]}\end{array}$ & {$[\wedge p]\left(' o p^{\prime}\right)$} & 9 & ++ & $\mathrm{Ja}$ & Fonologie & 2 \\
\hline & $\begin{array}{l}\text { Realisatie } \\
\text { scherplange [e:] } \\
\text { als tweeklank }\end{array}$ & $\begin{array}{c}\text { [breət] } \\
\text { ('breed') }\end{array}$ & 8 & ++ & Ja & Fonologie & 1 \\
\hline & Palatalisatie -je & $\begin{array}{l}\text { [mant]ə] } \\
\text { ('mandje') }\end{array}$ & 8 & ++ & Nee & Fonologie & 1 \\
\hline & $\begin{array}{l}\text { Klinkerverkor- } \\
\text { ting voor con- } \\
\text { sonantclusters }\end{array}$ & $\begin{array}{l}\text { [həwIst] ('ge- } \\
\text { weest') }\end{array}$ & 7 & $\begin{array}{l}\text { woordafhanke- } \\
\text { lijk }\end{array}$ & $\mathrm{Ja}$ & Fonologie & 1 \\
\hline
\end{tabular}

11 Regionale verspreiding: $+=<$ West-Vlaams dialectgebied, $++=$ West-Vlaams dialectgebied, +++ $=$ West- en Oost-Vlaams, $++++=>$ West- en Oost-Vlaams, $+++++=$ West-Vlaams \& Brabants (maar niet Oost-Vlaams) 


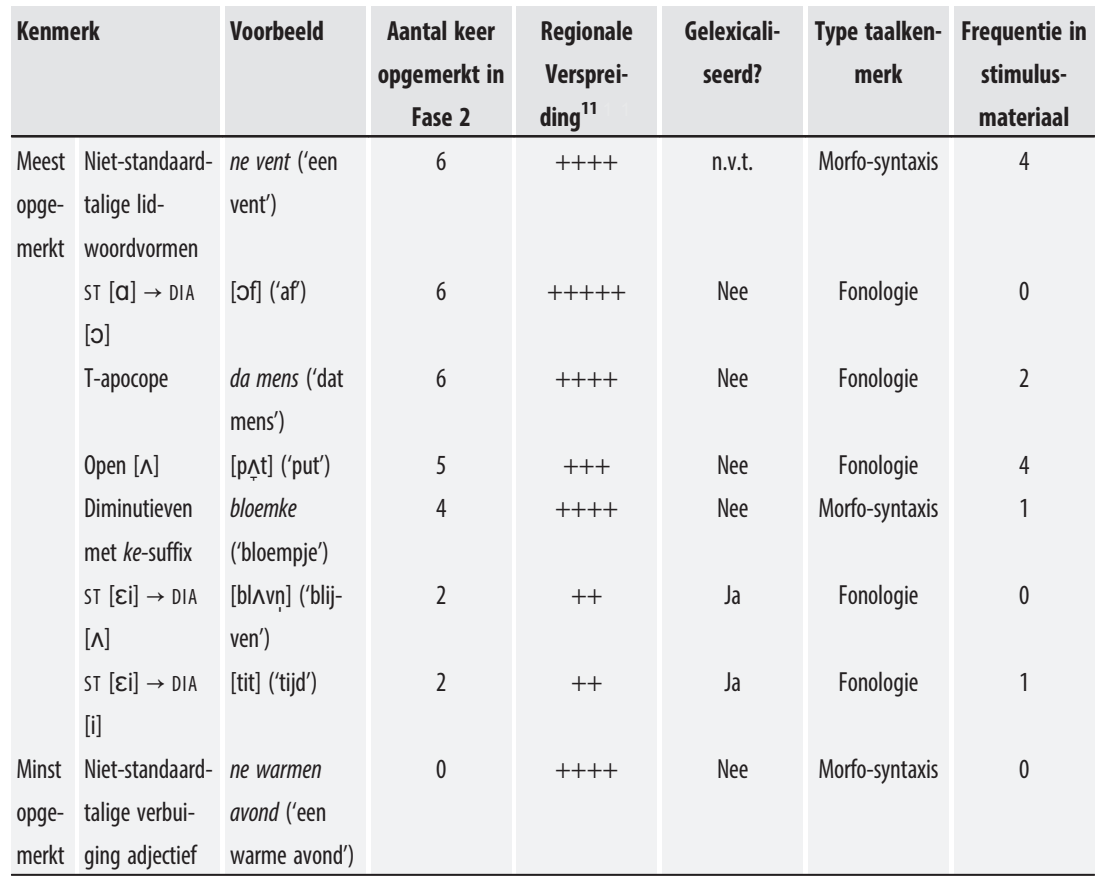

Een logistisch regressiemodel met lexicalisering, geografische verspreiding, taaldomein en frequentie in het stimulusmateriaal als fixed effects (cf. Tabel 5) toont dat de kans dat een kenmerk opgemerkt wordt significant beïnvloed is door de predictoren geografische verspreiding, taaldomein en frequentie in het stimulusmateriaal. Wat geografische spreiding betreft, stellen we vast dat de kans dat een kenmerk opgemerkt wordt, afneemt naarmate dat kenmerk een ruimer gebruiksgebied kent (cf. Schirmunski 1930, Schwob 1969, Van Bree 1992, Hinskens 1992, Kerswill \& Williams 2002, Lenz 2003). Zoals we in §3.7. al opmerkten, kan dat omgekeerd evenredige verband tussen ruimtelijke verbreiding en saillantie aan het effect van contrastwerking gelieerd worden: wijdverbreide varianten zoals $t$-deletie zijn voor zo veel Vlamingen endogeen in het eigen dialect dat ze weinig met andere varianten in aanraking komen en zich dus ook weinig bewust worden van het kenmerk in kwestie.

11 Regionale verspreiding: $+=<$ West-Vlaams dialectgebied, $++=$ West -Vlaams dialectgebied, +++ $=$ West- en Oost-Vlaams, $++++=>$ West- en Oost-Vlaams, $+++++=$ West-Vlaams \& Brabants (maar niet Oost-Vlaams) 
Tabel 5 Logistisch model verklarende factoren (dialectimitatiecontext weggelaten)

\begin{tabular}{|c|c|c|c|c|c|c|c|}
\hline \multicolumn{8}{|c|}{$\begin{array}{l}\text { Opgemerkt }_{(0=\text { nee, } 1=\text { ja) }}{ }^{-G^{-} \text {Geografie }}{ }_{(0=\text { verspreiding }<\text { West-Vlaams dialectgebie }} \\
(0=\text { gelexicaliserd })+\text { Frequentie in stimulusmateriaal }+1 \mid \text { Participant } \\
\mathrm{N}=2772\end{array}$} \\
\hline \multicolumn{2}{|c|}{ Random effects } & $n$ & Variantie & StdDev & & & \\
\hline \multicolumn{2}{|c|}{ Participant (Intercept) } & 56 & 0,225 & 0,475 & & & \\
\hline \multicolumn{2}{|c|}{ Fixed effects } & B & StdDev & $p$ & $\exp (B)$ & $\begin{array}{l}95 \% \mathrm{Cl} \exp \\
\text { (B) }\end{array}$ & \\
\hline \multicolumn{2}{|l|}{ (Intercept) } & $-1,65$ & 0,28 & $<0,001$ & 0,19 & $0,11-0,33$ & $* * *$ \\
\hline \multicolumn{2}{|c|}{$\begin{array}{l}\text { Geografie - West-Vlaams } \\
\text { dialectgebied }(++)\end{array}$} & $-0,81$ & 0,27 & 0,003 & 0,45 & $0,26-0,76$ & $* *$ \\
\hline \multicolumn{2}{|c|}{$\begin{array}{l}\text { Geografie - West- en } \\
\text { Oost-Vlaams dialect- } \\
\text { gebied }(+++)\end{array}$} & $-0,14$ & 0,26 & 0,60 & 0,87 & $0,53-1,45$ & \\
\hline \multicolumn{2}{|c|}{$\begin{array}{l}\text { Geografie - > West- en } \\
\text { Oost-Vlaams (++++) }\end{array}$} & $-1,17$ & 0,29 & $<0,001$ & 0,31 & $0,18-0,54$ & $* * *$ \\
\hline \multicolumn{2}{|c|}{$\begin{array}{l}\text { Geografie - West-Vlaams } \\
\text { en Brabants }(+++++)\end{array}$} & $-0,62$ & 0,32 & 0,05 & 0,54 & $0,29-1,01$ & . \\
\hline \multicolumn{2}{|c|}{$\begin{array}{l}\text { Taaldomein - Fonologie/ } \\
\text { morfo-syntaxis }\end{array}$} & $-0,01$ & 0,29 & 0,98 & 0,99 & $0,57-1,74$ & \\
\hline \multicolumn{2}{|c|}{$\begin{array}{l}\text { Taaldomein - Morfo-syn- } \\
\text { taxis }\end{array}$} & 0,11 & 0,22 & 0,61 & 1,12 & $0,73-1,72$ & \\
\hline \multicolumn{2}{|c|}{$\begin{array}{l}\text { Taaldomein - Woorden- } \\
\text { schat }\end{array}$} & 1,62 & 0,38 & $<0,001$ & 5,04 & $2,37-10,70$ & $* * *$ \\
\hline \multicolumn{2}{|c|}{ Lexicalisatie - Nee } & 0,10 & 0,14 & 0,48 & 1,10 & $0,84-1,44$ & \\
\hline \multicolumn{2}{|c|}{ Lexicalisatie - nvt } & $-0,10$ & 0,30 & 0,75 & 0,91 & $0,51-1,62$ & \\
\hline \multicolumn{2}{|l|}{ Frequentie } & 0,23 & 0,03 & $<0,001$ & 1,25 & $1,19-1,32$ & $* * *$ \\
\hline \multirow{3}{*}{$\begin{array}{l}\text { Model- } \\
\text { eigen- } \\
\text { schappen }\end{array}$} & kappa ${ }^{12}$ & $C$ & Null devi- & Residual & \multicolumn{3}{|c|}{ SSQ residuals vs residual df } \\
\hline & & & ance & deviance & Ratio & $x^{2}$ & $P$ \\
\hline & 22.05 & 0,75 & 2901,20 & 2629,99 & 0,93 & 2576,99 & 0,99 \\
\hline
\end{tabular}

12 De kappa-waarde, die een index vormt van multicollineariteit, berekenden we aan de hand van het R-script beschikbaar op https://hlplab.wordpress.com/2011/02/24/diagnosing-collinearity-in-lme4/. Een waarde boven 30 wijst op problematische multicollineariteit (Baayen 2008:182). De C-waarde, 'an index of the concordance between the predicted probability and the observed response' (Baayen 2008:204) werd berekend met de somers2-functie uit het R-pakket Hmisk. Een waarde van 0,5 wijst op willekeurige voorspellingen; een C-waarde van 1 op perfecte voorspellingen. 
Wat taaldomein betreft, blijkt uit de logistische regressie dat lexicale elementen significant vaker opgemerkt worden dan fonologische (Van Bree 1990). Tussen fonologie en morfo-syntaxis vonden we geen significante verschillen. Onze data ondersteunen zo Taeldemans hypothese (2009: 367) dat grammaticale elementen door hun grotere abstractie en structurele inbedding minder saillant zijn dan lexicale items.

De frequentie van de kenmerken in het stimulusmateriaal blijkt ook een determinerend effect te hebben op de kans dat een kenmerk opgemerkt wordt door de informanten: hoe vaker het kenmerk voorkwam in het materiaal, hoe groter de kans dat dat kenmerk opgemerkt werd. Dat frequentie-effect is o.i. vooral een methodologisch effect; bij het ontwerpen van saillantie-experimenten met stimuli moeten we indachtig zijn dat de samenstelling van die stimuli de resultaten sterk beïnvloedt. Uit de data mogen we niet concluderen dat kenmerken die in het dagelijkse leven frequenter voorkomen ook saillanter zijn (cf. hypothese van Bardovi-Harlig 1987). T-apocope komt in spontaan gesproken taalgebruik bijvoorbeeld frequenter voor dan niet-standaardtalige pronomina (zie corpusdata Ghyselen 2016: 333-334), en toch lijken die laatste taalkenmerken beduidend saillanter.

In §3.3. opperden we dat gelexicaliseerde taalkenmerken saillanter zouden zijn dan niet-exclusief gelexicaliseerde variabelen (cf. Schirmunski 1930). Onze resultaten blijken die hypothese niet te bevestigen: tussen gelexicaliseerde en niet-gelexicaliseerde kenmerken vinden we in het logistische model geen significante verschillen. We kunnen concluderen dat er vooral een correlatie is tussen regionale verspreiding en het taaldomein van een kenmerk enerzijds en de saillantie van dat kenmerk anderzijds, maar dat die correlatie niet absoluut is. Spreker- en contextgebonden factoren blijken eveneens een belangrijke rol te spelen, en die zorgen ervoor dat saillantie moeilijk te voorspellen is. Bovendien zijn er ook nog andere factoren - zoals mogelijk de al genoemde correctiepraktijken in het onderwijs - die de saillantie van taalkenmerken mee bepalen. De C-waarde van het net besproken logistische model blijft immers onder de drempelwaarde van 0,8 , wat aangeeft dat de factoren in het model niet volstaan om de saillantie van een kenmerk te kunnen voorspellen (Baayen 2008: 204). 


\section{$5 \quad$ Besluit}

Aan het begin van dit artikel formuleerden we de nood aan niet-circulaire methodes om saillantie te detecteren. We bespraken in $\S 2$ verschillende mogelijke benaderingen, waarvan we er verschillende combineerden in een casestudy: dialectimitatie, rechtstreekse expliciete bevraging en expliciete bevraging met stimulusmateriaal. Die 'multimethodologische' aanpak wierp duidelijk zijn vruchten af. Wat de dialectimitatiecontext betreft, merkten we dat de Brabantse informanten veel meer kenmerken imiteerden dan ze oorspronkelijk hadden opgegeven in hun interview. Het dialectimitatie-experiment bleek zo ideaal om het bekende probleem van 'gebrekkige metatalige competentie' bij perceptiestudies te omzeilen. De interviewsetting bleek echter evenzeer onmisbaar. Van sommige kenmerken waren de Brabanders zich bijvoorbeeld wel bewust - ze vermeldden ze in het interview - maar ze slaagden er niet in die te imiteren in de dialectimitatiecontext. Door de data van de imitatietests en de interviews samen te voegen, kon een diepgaander inzicht verkregen worden in de saillantie van West-Vlaamse dialectkenmerken. Ook de combinatie van gewone interviews met interviews op basis van stimulusmateriaal bleek relevant. Met interviews zonder stimuli wordt duidelijk welke kenmerken als stereotypen fungeren voor een bepaalde sprekersgroep in de taalgemeenschap, terwijl bevraging met stimuli de informanten een houvast geeft en hen in staat stelt talige gedachten beter onder woorden te brengen. Bij bevraging met stimuli dient men wel indachtig te zijn dat de samenstelling van het stimulusmateriaal, en vooral de frequentie van verschillende taalkenmerken in het stimulusmateriaal, de resultaten sterk beïnvloedt. Ideaal zou zijn om in de toekomst het stimulusmateriaal zo te manipuleren dat de frequentie niet-standaardtalige kenmerken in de stimuli een realistische weerspiegeling vormt van de frequentie van die kenmerken in spontane spraak.

Door de combinatie van methodes konden we een duidelijker beeld schetsen van de saillantie van een reeks West-Vlaamse taalvarianten en de factoren die daarbij een rol speelden. Een eerste vaststelling was dat saillantie geen a priori eigenschap van een taalvariant is; de regionale herkomst van een taalgebruiker speelt bij verschillende kenmerken een rol. Sommige kenmerken, zoals de gesloten realisatie van diftongen, worden sneller opgemerkt door sprekers die de kenmerken niet in hun lokale dialect kennen; terwijl andere, zoals sjwa-deletie, saillanter zijn voor taalgebruikers die de kenmerken zelf gebruiken. Daarnaast bleek er ook een duidelijke correlatie te bestaan tussen saillantie en het taaldomein waartoe 
een kenmerk gerekend kan worden. Door de band genomen bleken lexicale varianten immers saillanter dan fonologische en morfo-syntactische. We stelden bovendien een omgekeerd evenredig verband vast tussen de regionale verspreiding van een kenmerk en de saillantie ervan: hoe wijder een kenmerk verbreid is, hoe minder saillant. Hier kan ook de link gelegd worden met contrast: doordat een kenmerk wijdverbreid is, komen taalgebruikers minder in aanraking met equivalente varianten; die gebrekkige contrastwerking kan dan een lagere graad van saillantie verklaren. Tussen saillantie en lexicalisering konden we ten slotte geen duidelijk verband vinden.

Dit onderzoek kon duidelijk de voordelen aantonen van een multimethodologische aanpak ten opzichte van saillantie, maar heeft ook verschillende beperkingen. Zo werd in dit artikel enkel gefocust op de detectie van saillantie; een volgende stap is de rol te onderzoeken van saillantie bij dynamische processen zoals style-shifting en taalverandering. Bovendien zou een uitgebreidere studie met meer informanten een diepgaander inzicht moeten bieden in de cognitieve factoren die saillantie mee determineren. Wat is bijvoorbeeld de impact van de leeftijd of het geslacht van een taalgebruiker op zijn perceptie van taalkenmerken? Welke factoren uit de talige context stimuleren saillantie? We hopen met dit onderzoek een aantal methodologische tools aangereikt te hebben om saillantie te onderzoeken, en dat die kunnen helpen om meer inzicht te krijgen in de complexe interactie van saillantie met o.a. allerhande cognitieve en taalinterne factoren, de veranderingsgevoeligheid van taalkenmerken en de sociale evaluatie ervan.

\section{Referenties}

Anders, Christina Ada, Mrkus Hundt \& Alexander Lasch (red.) (2010). Perceptual Dialectology. Neue Wege der Dialektologie. Berlin/New York: De Gruyter.

Auer, Peter (2014). Anmerkungen zum Salienzbegriff in der Soziolinguistik. Linguistik Online 66, 7-20.

Auer, Peter, Birgit Barden \& Beate Großkopf (1998). Subjective and Objective Parameters Determining 'Salience' in Long-Term Dialect Accommodation. Journal of Sociolinguistics 2, 163-187.

Auer, Peter \& Frans Hinskens (2005). The role of interpersonal accommodation in a theory of language change. In: P. Auer, F. Hinskens \& P. Kerswill (red.), Dialect change. Convergence and Divergence in European Languages. Cambridge: Cambridge University Press, 335-357.

Baayen, R.H. (2008). Analyzing Linguistic Data. A Practical Introduction to Statistics using R. Cambridge: Cambridge University Press.

Bardovi-Harlig, Kathleen (1987). Markedness and salience in second-language acquisition. Language Learning 37, 385-407. 
Bree, Cor van (1990). De stabiliteit van de syntaxis en andere taalsectoren. Taal \& Tongval 3, 186210.

Bree, Cor van (1992). The stability of language elements in present-day eastern Standard Dutch and eastern Dutch dialects. In: J. A. Van Leuvensteijn \& J. Berns (red.) Dialect and Standard Language. Amsterdam: Royal Netherlands Academy of Arts and Sciences, 178-203.

Bree, Cor van (2000). Taalbewustzijn, taalverandering en regionale taalvariatie. Taal \& Tongval $52,22-46$.

Campbell-Kibler, Kathryn (2011). The sociolinguistic variant as a carrier of social meaning. Language Variation and Change 22, 423-441.

Cramer, Jennifer \& Chris Montgomery (red.) (2016). Cityscapes and perceptual dialectology. Global perspectives on non-linguists' knowledge of the dialect landscape. Boston/Berlin: De Gruyter.

Devos, Magda \& Reinhild Vandekerckhove (2005). West-Vlaams, Tielt: Lannoo.

Durham, Mercedes (2015). How to sound lush in 140 characters: Performing a Welsh accent on Twitter. Presentatie tijdens de conferentie ICLaVE8 in Leipzig.

Durham, Mercedes (2016). Changing attitudes towards the Welsh English accent: A view from Twitter. In: M. Durham \& J. Morris (red.), Sociolinguistics in Wales. London: Palgrave.

Eckert, Penelope (2012). Three waves of variation study: The emergence of meaning in the study of variation. Annual Review of Anthropology 41, 87-100.

Evans, Betsy E. (2002). An acoustic and perceptual analysis of imitation. In: D. Long \& D. Preston (red.), Handbook of Perceptual Dialectology. Volume 2. Amsterdam/Philadelphia: John Benjamins Publishing Company, 95-112.

Ghyselen, Anne-Sophie (2009). Ne zelfzekere leraar of gewoon nen enthousiaste mens? Een matched-guise onderzoek naar de attitude tegenover tussentaal bij West-Vlamingen. Taal en Tongval 61, 83-113.

Ghyselen, Anne-Sophie (2011). Structuur en dynamiek van diaglossische taalrepertoria: een pleidooi voor meer empirisch onderzoek. Belgische Kring Voor Linguïstiek 6, 1-28.

Ghyselen, Anne-Sophie. (2016). Verticale structuur en dynamiek van het gesproken Nederlands in Vlaanderen: een empirische studie in Ieper, Gent en Antwerpen. Universiteit Gent: doctoraatsverhandeling.

Hickey, Raymond (2000). Salience, stigma and standard. In: L. Wright (red.), The development of standard English 1300-180o. Theories, descriptions, conflicts. London: Cambridge University Press, 57-72.

Hinskens, Frans. (1992). Dialect levelling in Limburg: Structural and sociolinguistic aspects. Universiteit Nijmegen: doctoraatsverhandeling.

Hundt, Markus, Ada Christina Anders \& Alexander Lasch (2010). Gegenstand und Ergebnisse der Wahrnehmungsdialektologie. In: A. C. Anders, M. Hundt \& A. Lasch (red.), Perceptual Dialectology. Neuwe Wege der Dialektologie. Berlin/New York: De Gruyter, xi-xxi.

Jaspers, Jürgen \& Heleen Mercelis (2015). Kijk, ik spreek illegaals! Taal en taalnormen in de hedendaagse stad. Internationale Neerlandistiek 52, 201-219.

Kerswill, Paul \& Ann Williams (2002). 'Salience' as an explanatory factor in language change: evidence from dialect levelling in urban England. Reading Working Papers in Linguistics 4, 6394.

Kleene, Andrea (te verschijnen). Zur Salienz morphosyntaktischer Phänomene des Bairischen. In: T. Ahlers, S. Oberholzer, M. Riccabona \& P. Stoeckle (red.), Deutsche Dialekte in Europa. Perspektiven auf Variation, Wandel und Übergänge. Hildesheim: Georg Olms Verlag (= Kleine und regionale Sprachen),

Lenz, Alexandra (2003). Struktur und Dynamik des Substandards. Eine Studie zum Westmiddeldeutschen (Wittlich/Eifel). Stuttgart: Steiner.

Lenz, Alexandra (2010). Zum Salienzbegriff und zum Nachweis salienter Merkmale. In: A. C. 
Anders, M. Hundt \& A. Lasch (red.) Perceptual Dialectology. Neue Wege der Dialectologie. Berlin/New York: De Gruyter, 89-110.

Long, Daniel \& Dennis Preston (red.) (2002). Handbook of perceptual dialectology. Amsterdam/ Philadelphia: Benjamins.

Lybaert, Chloé (2014). Perceptie van intermediair taalgebruik in het gesproken Nederlands in Vlaanderen: een experimentele benadering van saillantie. Nederlandse Taalkunde 19, 185-220.

Markham, Duncan (1999). Listeners and disguised voices: The imitation and perception of dialectal accent. Forensic Linguistics 6, 87-131.

Preston, Dennis (red.) (1999a). Handbook of perceptual dialectology. Amsterdam/Philadelphia: Benjamins.

Preston, Dennis (2010a). Language, people, salience, space: perceptual dialectology and language regard. Dialectologia 5, 289-299.

Preston, Dennis (2010b). Perceptual dialectology in the 21st Century. In: C. A. Anders, M. Hundt \& A. Lasch (red.), Perceptual dialectology. Neue Wege der Dialektologie. Berlin/New York: De Gruyter, 1-29.

Preston, Dennis R. (1989). Perceptual dialectology. Nonlinguists' views of areal linguistics, Dordrecht: Foris Publications.

Preston, Dennis R. (1999b). Introduction. In: D. R. Preston (red.), Handbook of Perceptual Dialectology. Volume 1. Amsterdam/Philadelphia: Benjamins, xxiii-xl.

Purschke, Christoph (2010). Imitation und Hörerurteil - Kognitive Dialekt-Prototypen am Beispiel des Hessischen. In: C. A. Anders, M. Hundt \& A. Lasch (red.), Perceptual Dialectology. Neue Wege der Dialektologie. Berlin/New York: De Gruyter, 151-177.

Rácz, Péter (2012). Operationalising salience: definite article reduction in the North of England. English Language and Linguistics 16, 57-79.

Rosner, B.S. \& Brian Pickering (1994). Vowel perception and production. Oxford: Oxford University Press.

Rys, Kathy \& Johan Taeldeman (2007). Fonologische ingrediënten van Vlaamse tussentaal. In: D. Sandra, R. Rymenans, P. Cuvelier \& P. Van Petegem (red.), Tussen taal, spelling en onderwijs. Essays bij het emeritaat van Frans Daems. Gent: Academia Press, 1-8.

Schirmunski, Victor (1928/1929). Die schwäbischen Mundarten in Transkaukasien und Südukraine. Zeitschrift für deutsche Dialektforschung und Sprachgeschichte 5, 38-171.

Schirmunski, Victor (1930). Sprachgeschichte und Siedelungsmundarten. Germanisch-Romanische Monatschrift 18, 113-122/171-188.

Schwob, Anton (1969). Sprachausgleich in einer moselfränkischen Siedlungsmundart. Inssbrucker Beiträge zur Kulturwissenschaft 15, 311-356.

Segerup, My. (1999). Imitation of Dialects: from South Swedish to West-Swedish. In: J. J. Ohala (red.), ICphS9g. Berkley: University of California, 1253-1256.

Taeldeman, Johan (1993). Dialectresistentie en dialectverlies op fonologisch gebied. Taal \& Tongval Themanummer 6, 102-118.

Taeldeman, Johan (2009). Linguistic stability in a language space. In: P. Auer \& J. E. Schmidt (red.) Language and space: an international handbook of linguistic variation. Berlin: De Gruyter Mouton, 355-374.

Trudgill, Peter (1986). Dialects in Contact. Oxford: Blackwell. 


\section{Over de auteurs}

\section{Pieternelle Vandekerckhove}

E-mail: pieternelle_vandekerckhove@hotmail.com

Anne-Sophie Ghyselen, Universiteit Gent, Vakgroep Taalkunde

E-mail: annesophie.ghyselen@ugent.be 
